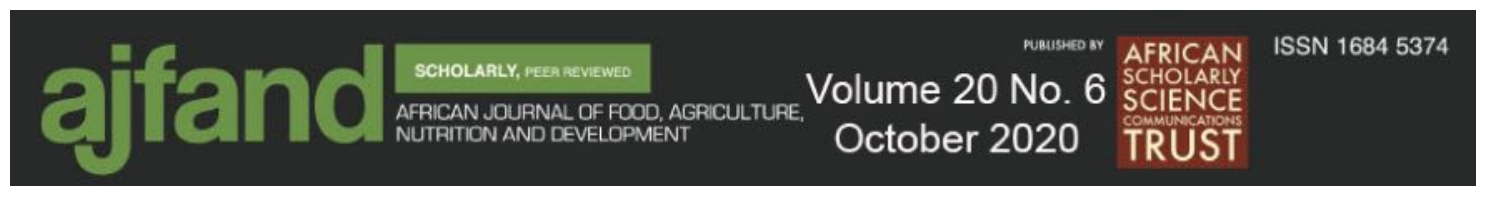

Afr. J. Food Agric. Nutr. Dev. 2020; 20(6): 16585-16603

https://doi.org/10.18697/ajfand.94.19920

\title{
DIETARY INTAKE AND COGNITIVE DEVELOPMENT AMONG CHILDREN IN KISUMU COUNTY, KENYA
}

Sawe $\mathbf{C J}^{1 *}$, Kogi-Makau W' ${ }^{1}$, Ettyang GAK ${ }^{2}$ and CO Kimamo ${ }^{3}$



Sawe Caroline

*Corresponding author email: carolsawej@yahoo.com

${ }^{1}$ Department of Food Science, Nutrition and Technology, College of Agriculture and Veterinary Sciences, University of Nairobi, Kenya

${ }^{2}$ Department of Health Policy, Management and Human Nutrition, College of Health Sciences, Moi University, Eldoret, Kenya

${ }^{3}$ Department of Psychology, College of Humanities and Social Sciences, University of Nairobi, Kenya 


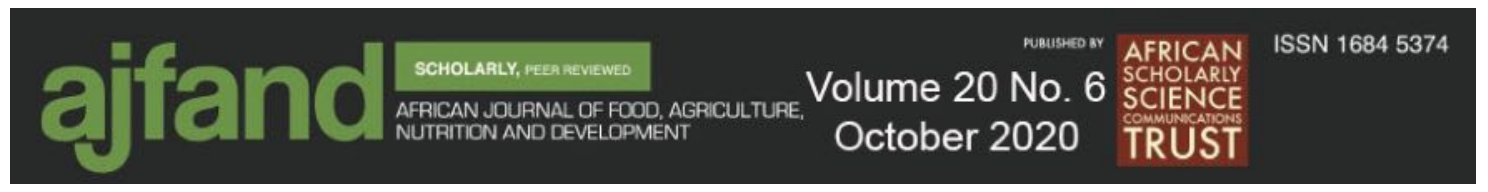

\section{ABSTRACT}

Varied nutrient-dense and high-quality diet are key to ideal growth and cognitive function in the early years of life. Nutrient deficiency can lead to negative functional effects of the brain and poor cognitive function. High rates of poverty in developing countries predispose children to malnutrition. This study aimed at exploring factors associated with dietary intake and cognitive development among children in Kisumu County, Kenya. This was a cross-sectional study survey that recruited 192 children aged less than 24 months. Food frequency questionnaire and Bayleys Scale for Infant Development kit was used to collect data. It was revealed that a total of $51 \%$ were girls with 30\% aged below 6 months. Only 12\% had cognitive scores above average. Child cognitive scores were linked with age $(p=0.022)$, carbohydrate $(p=0.021)$, fat $(p=0.011)$ and iron $(p=0.022)$ intake. Only $34 \%$ and $32 \%$ of children consumed diets adequate in proteins and iron, respectively. Of children aged above 18 months, only 13\% consumed diet adequate in iron. Factors associated with carbohydrate intake included: mother's marital status $(p=0.036)$ and her level of income $(p=0.028)$ while protein intake related to the type of housing $(\mathrm{p}=0.013)$. Fat intake was linked with the mother's marital status $(p=0.009)$ and her level of income $(p=0.001)$ while the iron intake was linked to the mother's level of income $(p=<0.001)$ and her educational level $(p<0.001)$. Vitamin A intake was linked to the ability to pay rent by the household $(p=0.016)$. Further analysis revealed that children whose fathers were earning more than Kenya shillings 3000.00 per month had 0.2 times lower risk of being above average on cognitive scores compared to those whose fathers were earning less than Kenya shillings 3000.00 per month, while those with an inadequate intake of carbohydrate had 8 times more risk of having cognitive scores above average compared to those whose diets were adequate. In conclusion, majority of children consumed diets inadequate in protein and iron while $12 \%$ of children had cognitive scores above average. Mother's marital status, eduation and income influenced child's dietary intake while their age groups and father's income were associated with child's cognitive outcomes. Policies to enhance parental education and income level should be formulated to improve child's dietary and cognitive outcomes.

Key words: Dietary intake, Cognitive development, Children, Bayleys Scale for Infant Development, Malnutrition 


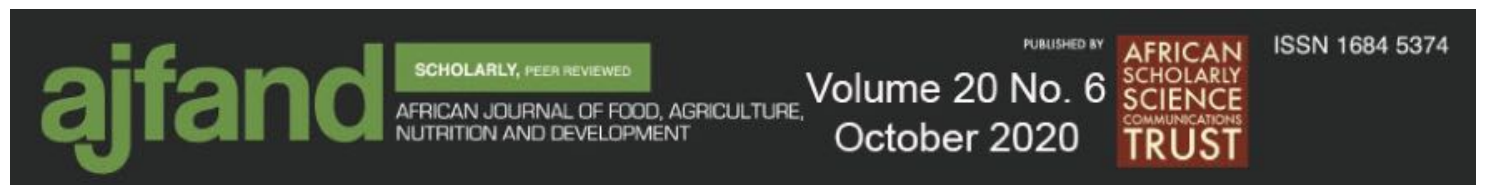

\section{INTRODUCTION}

Good nutrition in the early years of life is key for ideal growth and cognitive development. A varied nutrient-dense diet has a direct link to growth, immunity, cognitive function and the academic performance of an individual later in life [1,2]. Due to high rates of poverty in developing countries, most children consume low-quality diets that predispose them to malnutrition. As they grow, they develop motor skills to feed themselves, hence influencing their dietary intake as they can choose what and not what to consume [3]. It has been proved that poorly nourished children are susceptible to infections, have decreased activity levels, low interests to play, reduced social activities and curiosity; and low cognition function [4-6]. A Guatemalan study revealed that children with insufficient energy were not taking full advantage of the social and learning activities around them [7].

Poor nutrition in the first 1,000 days of life has undesirable effects on a child's ability to grow. It can also lead to stunting, an irreversible condition that has been linked to reduced cognitive ability; and reduced school and work performance $[2,8]$. Most growth faltering in children occurs after exclusive breastfeeding has been stopped, a time when disease exposure and nutritional needs are high due to the rapid growth and development.

World Health Organization (WHO) together with UNICEF recommends that children be exclusively breastfed for the first six months of life as breast milk provides best and ideal nutrients for growth and development. The long-term benefits of exclusive breastfeeding are better intelligence test performance in later years. Nutrients in breast milk are required for rapid development of immature brain and recent studies have shown that children who were exclusively breastfed and or were breastfed for a longer time had a higher score on visual tests compared to their counterparts who were formula-fed [9]. The WHO actively supports, promotes and advocates for mothers and families to initiate and maintain optimal breastfeeding practices [10].

Macro and micronutrients that are key in cognitive development are not limited to carbohydrate, protein, fats, iron, iodine, zinc calcium, magnesium folic acid, vitamin A and $\mathrm{B}$ complex $[11,12]$. These key nutrients have been proved to have a direct impact on cognitive function since they aid in the metabolism of neurons and synthesis of neurotransmitters. Deficiency of these nutrients could result in negative functional effects of the brain and poor cognitive function. Children with nutritional deficiencies are mostly those from disadvantaged and poor environments. Research findings have shown that iron deficiency anemia has been associated with psychomotor developmental delays and lowers the cognitive development of children, especially in the early years. Iron deficiency has also been linked to a reduction in IQ by almost 9 points and anemic preschoolers have been seen to be having problems in maintaining class concentration [13]. Lack of or reduced iodine and iron in the bodies have been linked with delayed cognitive functioning in children while zinc deficiency has been connected with a reduction in child activity and motor development [14]. A study by Neumann et al. [15] in Embu among primary school pupils revealed a low school achievement that was associated with iron deficiency. 


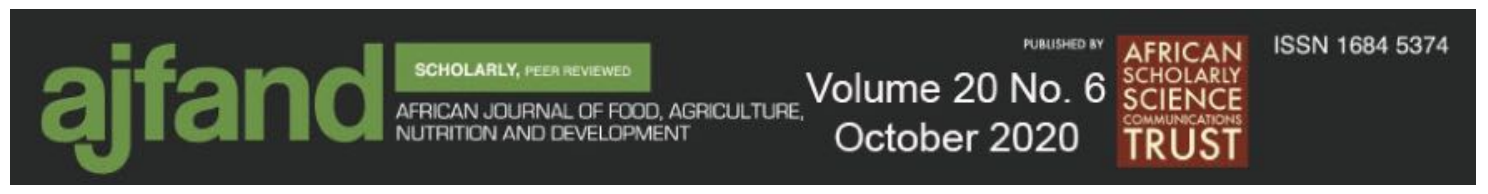

After infancy, it is very difficult to reverse any cognitive deficit since malnutrition in early life creates a greater undesirable impact on cognitive development than in the later years $[15,16]$. Therefore, in countries where the prevalence of malnutrition is high, programs aiming at improving children's nutritional and cognitive outcomes should be introduced and target children below two years of age [17]. In its 2010 report, WHO showed that poor nutrition was the underlying cause of about $33 \%$ of deaths among children under the age of two. It also reported that $18 \%$ of children under two years of age were underweight and over 86 million had stunted growth $[18,19]$. This shows that poor dietary intake among young children can be a predictor of functional impairment $[8,20]$. After a nutrition intervention in Guatemala, there was a significant increase in the cognitive development among preschoolers who were on supplementary feeding and a decrease in the number of student dropouts as indicated by Engle and Fernandez [21]. Another study by Whaley et al. [22] in Embu Kenya found that animal source foods had a specific domain of cognitive function among school-going children and recommended for extensive nutrition education to improve the quality of diets as it had shown to have affected the human cognitive function. Other studies have also recommended nutritional interventions that address the growth and learning abilities of children [23]. Compared to developed countries, limited studies have been conducted in developing countries on the relationship between nutrition, cognitive development and their determinants among young children. This study, therefore, aimed at exploring the factors associated with dietary intake and cognitive development among children in Kisumu County, Kenya.

\section{METHODS}

\section{Study Design and population}

This study was a cross-sectional survey that recruited 192 children aged less than 24 months from Kisumu County in Kenya. Data were collected using a quantitative method. Children were sampled into age strata in the proportion of 2: 3:3:2 for the ages below 6 months; between 6 and 12 months; between 13 and 18 months; and between 19 and 24 months, respectively. From each stratum, children were randomly selected until the desired sample was attained. Research Assistants (RA) sought consent from the caretakers of the children before recruiting them. The caretakers who were willing for their children to participate assented and gave information on behalf of their children. Questionnaires on the social demographic characteristics and food frequencies were administered to the caretakers. For the cognitive assessment, caretakers were requested to assist in administering the Bayleys Scale for Infant Development kit to the children with the guidance of the RAs. The RAs were trained to administer the data collection tools. Administration of questionnaires and assessments per child took between 40 and 60 minutes.

\section{Inclusion and exclusion criteria}

Children aged less than two years and their caretakers residing in the study area were included in the study. Those with chronic conditions like cancers and cardiovascular diseases and or were on prescribed drugs at the time of data collection were excluded from the study. This is because these conditions have been known to have a negative impact on the dietary intake and cognitive function of the children and, therefore, could affect the quality of the data collected. 


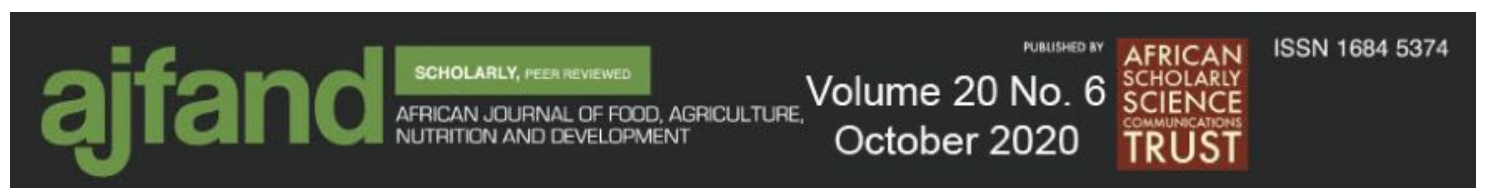

\section{Data collection tools}

\section{Socio-demographic characteristics}

Questionnaire on socio-demographic characteristics collected data on child's sex and age, mother's marital status, income and education level; father's income level; type and size of house children lived in, how much they paid for rent for those in such houses; and if the mother owned a phone.

\section{Cognitive assessment}

Cognitive development in children was assessed using the Bayley Scales for Infant Development, Third Edition (BSID-111), a tool that was standardized in the USA. This tool assessed three domains; cognitive, language and motor.

The cognitive domain was assessed by how a child remembered certain tasks, reacted, learned and manipulated the surrounding environment, how they counted, explored objects visually and physically, assembled objects, finished a puzzle, identified colours, matched masses, discriminated patterns and how they presented an imaginary play.

The language domain assessed the receptive and expressive communication of a child. This was assessed by how they recognized sounds and understood spoken words and directions, and how they communicated using sounds, gestures and words; communications through babbling, use of gestures, new word development such as naming items, images and actions; development of morpho-syntactic sentences like use of several words in a sentence and the use of plural, tenses; and the ability to identify objects and pictures that are referenced.

Motor domain assessed both fine and gross motor. Fine motor was assessed by how a child used their hands and fingers to make things happen and the skills evaluated included; visual tracking, how they reached for objects and how they manipulated them, the different ways of grasping, how they walked, hand functional abilities and how they responded to physical information. Gross motor was assessed by gauging how children moved their bodies ( how they controlled their heads, sat, stood), dynamic movement (crawling, walking, jumping, walking up and downstairs), and quality of movement (leg coordination when they walk, stood and kicked), balancing and imitating postures [24].

Appealing toys and activities were used to stimulate a child's interests. Children interacted with these appealing toys and performed various tasks to evaluate their thinking, language and movement (sitting, walking). These tasks ranged from basic to complex depending on the child's age. With the assistance of the caretakers, RAs instructed on the tasks as they observed and scored. In some tasks, children were given up to one minute and others were given up to three trials before a score was given. A completed task earned one mark while incomplete or failed task earned zero mark. The RA scored each task and then tallied. The quantitative composite scores were computed, categorized then the child's estimated cognitive scores compared with qualitative scores of children of similar age. Children whose qualitative scores were found to be above or equal to 110.0 were classified as above average, between 90.0 and 119.9 as average and those below or equal to 89.9 as below average. This is as summarized on table 1 . 


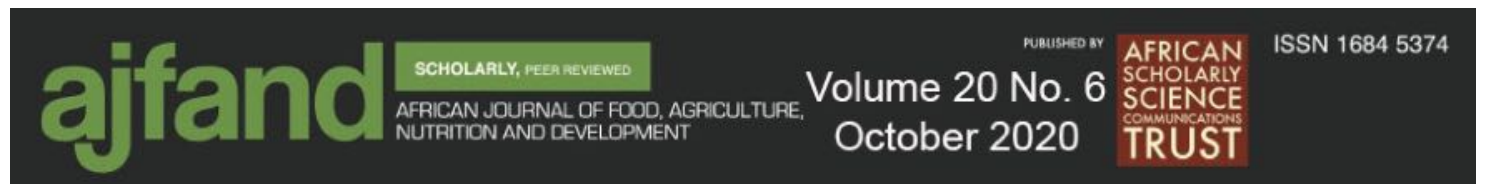

\section{Dietary assessment}

In determining the dietary intake of children, Food Frequency Questionnaire (FFQ) was used. The FFQ approximates the typical dietary intake of a child for up to one month. In this study, it was administered to caretakers to determine the average daily food intake of the children based on locally consumed foods in the region. The caretakers of the children were probed and model pictures of local foods used to ask if the children had consumed certain foods in the past month and if so, in what estimated amount per each meal.

The computed daily nutrient intake was compared with the Recommended Daily Allowances (RDA)s. The RDAs as shown in Table 2 provided average daily consumption of foods that were adequate to meet the nutrient requirement for nearly $98 \%$ of healthy persons according to different age groups [25]. The key nutrients for this study were carbohydrate, proteins, fat, iron and vitamin A. The FFQ for this study had a total of 26 locally consumed foods. Caretakers assented and gave this information on behalf of their children.

\section{Statistical analysis}

Data from cognitive development assessments yielded standard scores that estimated the child's cognitive scores and compared to other children of similar age, while daily nutrient intake was computed for each child using the Moi University NutriCal software. The specific nutrients computed included carbohydrates, proteins, fats, iron and Vitamin A. Data from socio-demographic characteristics were merged with data from cognitive scores and daily nutrient intake in the STATA version 14.0 and analysis done. Descriptive statistics described the characteristics of the children, while chi square tests analyzed the relationship between dietary intake, cognitive scores and socio demographic characteristics of the children. Multiple logistic regression assessed the factors in socio demographic characteristics that were associated with child dietary intake and cognitive scores. The level of statistical significance was set at $\mathrm{P}<0.05$. All independent values that had $\mathrm{p} \leq 0.05$ at chi square tests analysis were considered at logistic regression.

\section{Ethical approval}

Ethical approval and clearance were sought from Moi University Institutional Research and Ethical Committee Approval number 0001567. Since the study was dealing with sensitive issues on children aged less than two years, confidentiality was ensured by using anonymous numbers to identify them. After explaining the purpose of the study, the caretakers who accepted their children to participate in the study voluntarily assented on behalf of their children. All research assistants had to do and pass the online Protection of Human Subjects tests before collecting data. Data from the field were sealed in envelopes, transported and kept under lock and key in the Researcher's office. Data entered in the computer were protected using a password. 


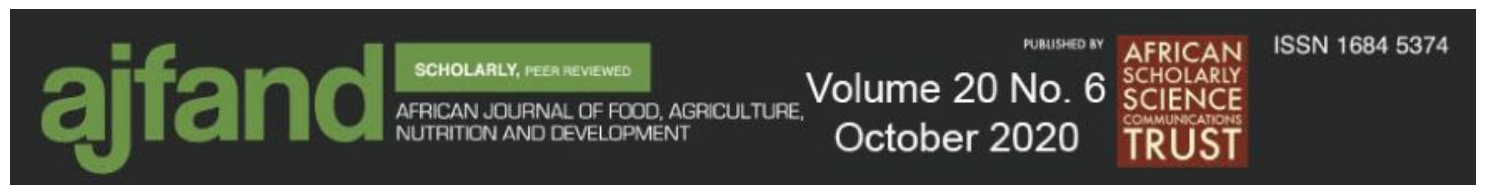

\section{RESULTS AND DISCUSSION}

\section{Demographic characteristics}

Of all the 192 children (Table 3), 51\% were girls, while those aged between 6 and 12 months constituted $30 \%$. A total of $68 \%$ of mothers of the children were married with $79 \%$ and $62 \%$ of mothers and fathers earning less than Kenya shillings (Ksh) 3000.00 per month, respectively while $40 \%$ of fathers had not schooled beyond secondary level. It was also observed that $55 \%$ of children lived in semi-permanent houses while $42 \%$ lived in double room houses. Those who lived in rental houses and paid less than Ksh 3000.00 per month accounted for $45 \%$, while $95 \%$ of mothers owned mobile phones.

\section{Level of Cognitive Development}

Figure 1 shows that $25 \%$ and $12 \%$ of the children had their cognitive scores being below and above average, respectively.

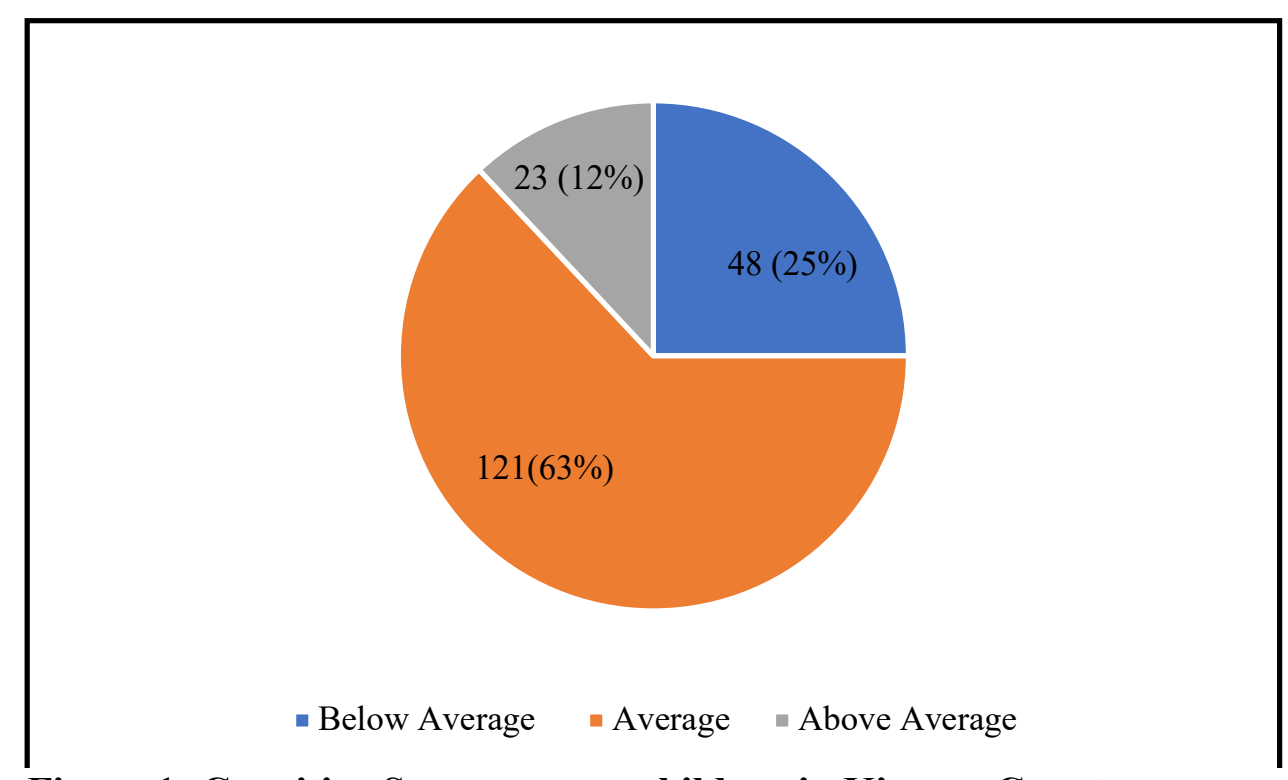

Figure 1: Cognitive Scores among children in Kisumu County

\section{Dietary intake}

As indicated in table 4 , only $34 \%$ and $32 \%$ of children consumed diets that were adequate in protein and iron sources, respectively. Children in the ages between 19 and 24 months were highly affected with only $21 \%$ and $13 \%$ of them consuming diets rich in protein and iron sources, respectively. The adequacy of nutrient intake was tabulated using the Recommended Daily Allowances for children according to their ages. There was a significant relationship between the intake of protein $\left(\mathrm{Chi}^{2}=8.3188, \mathrm{p}=0.040\right)$ and iron $\left(\mathrm{Chi}^{2}=11.7102, \mathrm{p}=0.008\right)$ with the age groups of the children. A nutrient-dense diet is key for a child well being. It was revealed that a child's diet was sufficient in carbohydrates $(90 \%)$, fats $(75 \%)$, and Vitamin A (84\%).

Due to the high poverty levels in developing countries, foods rich in proteins and iron are expensive to purchase, and thus may deny household members especially children the benefits of these key nutrients. Families could prefer carbohydrate-rich foods since 


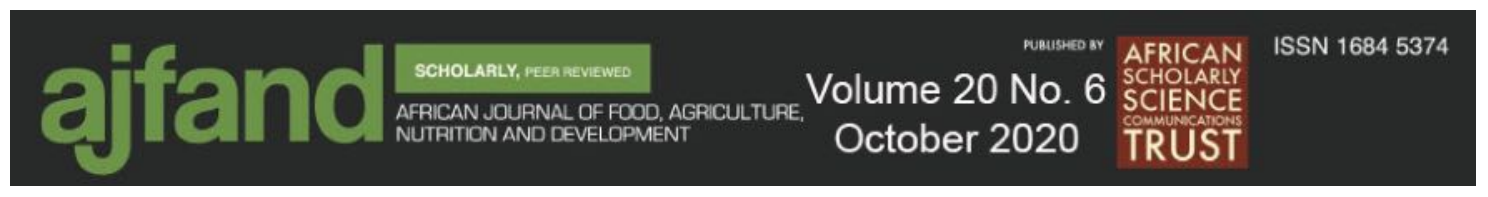

they are readily available and affordable; since small amounts of fats are required in the cooking process, most households could afford them and hence they could be available in recommended amounts [26]. Organ meats are excellent sources of heme iron while animal-source proteins have high biological value in our bodies. However culturally, these foods are preserved for the elderly population and are a taboo for young children to consume [27]. This denies children the benefits of these key nutrients. Findings from this study agreed with studies done in the Netherlands and the USA that had observed that only $50 \%$ and $26 \%$ of children consumed diets that were rich in protein and iron, respectively $[28,29]$.

Children aged between 18 and 24 months were highly affected with only $21 \%$ and $13 \%$ of them consuming diets adequate in protein and iron, respectively. At this critical age, children are independent, can partially feed themselves and have control over what to and not to consume. Most could prefer sweet over unpleasant foods [3]. By the time a child is 18 months, most mothers are already pregnant and their concentration and income have been diverted to the unborn baby. Therefore, expensive foods like proteins and those heme iron sources of iron are rarely purchased [30]. Vitamin A is crucial for vision and brain function with some of its cheap food sources including orange-yellow vegetables and fruits like pumpkins and carrots. Its high intake among young children could be due to awareness of its significance on brain development by health workers both at the community and health facilities [31].

\section{Determinants of cognitive development and dietary intake}

As revealed in table 5, consumption of foods rich in carbohydrate $\left(\mathrm{Chi}^{2}=7.7133\right.$, $\mathrm{p}=0.021)$, fat $\left(\mathrm{Chi}^{2}=7.4207, \mathrm{p}=0.011\right)$ and iron $(\mathrm{Chi} 2=7.2854, \mathrm{p}=0.022)$ were associated with cognitive development among children. These nutrients are key in brain development and cognitive development among children. On further analysis as indicated on Table 7, children whose fathers were earning more than Kenya shillings 3000.00 per month had 0.2 times lower risk of being above average on cognitive score compared to those whose fathers were earning less than Kenya shillings 3000.00 per month [RRR:0.292:95\% CI:0.089-0.957; $\mathrm{p}=0.043$ ] while children whose diets were inadequate in carbohydrate intake had 8 times more risk of having cognitive score that was above average compared to those diets were adequate [RRR:8.230:95\% CI:1.21155.928; $\mathrm{p}=0.031]$.

Fathers with higher income can provide resources like food, housing, and stimulating materials for their children which in turn can lead to improved cognitive outcomes. A study by Cabrera and Peters agreed that financially stable fathers were able to positively interact with their children, had more stable relationships with their spouses, which promoted a better home environment for better child cognitive development [32]. Consumption of adequate carbohydrates in the diet has been associated with higher concentration among children and reduced risks of obesity, other non-communicable diseases and better cognitive function [33].

As shown in table 6 , mother's marital status $(p=0.036)$, her level of income $(p=0.028)$ and type of house family lived in $(\mathrm{p}<0.001)$ were linked to carbohydrate intake, while a child's age group ( $p=0.04)$, a mother's level of income $(p<0.001)$, her highest level of 


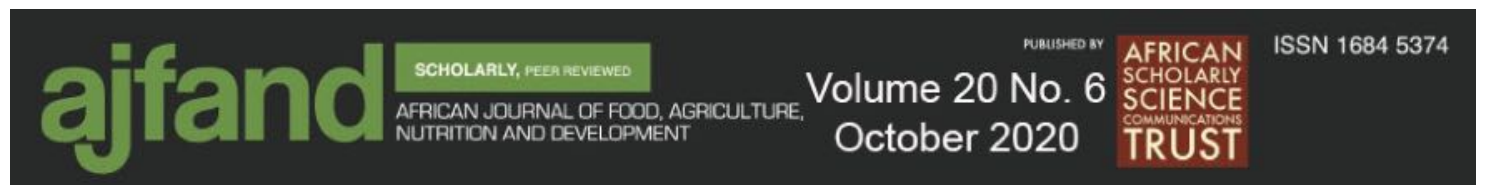

education attained $(p<0.0001)$, type of house $(p=0.013)$, size of house $(p=0.013)$ and family's rental pay $(\mathrm{p}=0.047)$ were associated with protein intake. It was also found that there was a relationship between a mother's marital status $(\mathrm{p}=0.009)$, her level of income $(p=0.001)$, size of house the family lived in $(p=0.015)$, the family's rental pay $(p=0.005)$ and ability of the mother to own a phone $(\mathrm{p}=0.030)$ with the child's fat intake, while iron intake related with the child' age group $(\mathrm{p}=0.008)$, a mother's level of income $(\mathrm{p}<0.001)$, her highest education level attained $(\mathrm{p}<0.001)$ and ability to own a home $\mathrm{p}=$ 0.046). Vitamin A intake was only found to be associated with a family's ability to owning a house $(\mathrm{p}=0.016)$.

In African settings, where extended families are still treasured even among married couples, one has to get foods that are readily available and affordable like carbohydrates; and fats that are used in small amounts during the cooking process [26] to ensure the diet is adequate for all family members including young children. The level of a mother's income, education level and ability to pay rent was associated with protein and iron intake. Compared to illiterate mothers, those educated are more likely to have some source of income and could be knowledgable on nutrition issues and could make a better decision on purchasing expensive nutritious foods including protein and iron sources [34]. Families owning homes could be having little savings that can allow them to purchase nutritious foods while those mothers with phones can use various food applications to make choices for their children [35].

\section{CONCLUSION}

Majority of children consume diets that are inadequate in protein and iron, while $12 \%$ of chilren have cognitive scores that are above average. Dietary intake among children is influenced by mother's marital status, her education and income levels, while cognitive development is associated with a child's age group and the father's level of income. Parental income and education should be improved while policies aimed at improving dietary intake and cognitive development among children need to be formulated and implemented. Further research is suggested to explore the relationship between diet and cognitive function and their determinants.

\section{ACKNOWLEDGEMENTS}

"This research was supported by the Consortium for Advanced Research Training in Africa (CARTA). CARTA is jointly led by the African Population and Health Research Center and the University of the Witwatersrand and funded by the Carnegie Corporation of New York (Grant No--B 8606.R02), Sida (Grant No:54100113), the DELTAS Africa Initiative (Grant No: 107768/Z/15/Z) and Deutscher Akademischer Austauschdienst (DAAD). The DELTAS Africa Initiative is an independent funding scheme of the African Academy of Sciences (AAS)'s Alliance for Accelerating Excellence in Science in Africa (AESA) and supported by the New Partnership for Africa's Development Planning and Coordinating Agency (NEPAD Agency) with funding from the Wellcome Trust (UK) and the UK government. The statements made and views expressed are solely the responsibility of the Fellow". 




\section{AUTHOR CONTRIBUTION}

Caroline Sawe is the main researcher and student who conceptualised and collected data. She did data analysis and interpretation, and drafted and finalized this manuscript. KM, GE and CK are student supervisors and they all provided the guidance from conceptualization of the research objectives, methodology, data collection, analysis, and interpretation of the results. All were key in development, drafting and finalizing of this manuscipt.

Author disclosures: Authors report no conflicts of interest. 


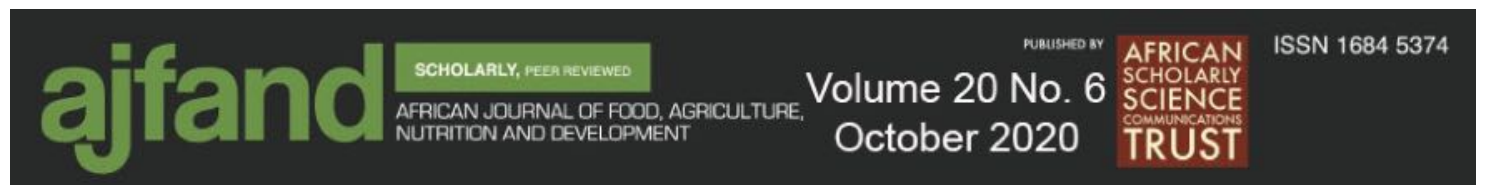

Table 1: Qualitative Bayley Composite Score

\begin{tabular}{ll}
\hline Quantitative Score & Qualitative Evaluation \\
\hline$\geq 110.0$ & Above Average \\
$90.0-109.9$ & Average \\
$\leq 89.9$ & Low average \\
\hline
\end{tabular}

Source: Bayley Scale of Infant Development $3^{\text {rd }}$ edition technical manual

Table 1: RDA for infants and Toddlers

\begin{tabular}{lllll}
\hline Nutrient & \multicolumn{4}{l}{ Age groups in months } \\
\cline { 2 - 5 } & $<\mathbf{6}$ & $\mathbf{6}$ to $<\mathbf{1 2}$ & $\mathbf{1 2}$ to $<\mathbf{1 8}$ & $\mathbf{1 8}$ to $<\mathbf{2 4}$ \\
\hline Energy $(\mathrm{Kcal} / \mathrm{kg})$ & 108 & 98 & 98 & 1240 \\
\hline Protein $(\mathrm{mg} / \mathrm{kg})$ & 2.05 & 1.65 & 1.65 & 22 \\
\hline Fat $(\mathrm{mg})$ & 6 & 10 & 10 & 25 \\
\hline Iron $(\mathrm{mg} / \mathrm{kg})$ & 1.0 & 1.0 & 1.0 & 12 \\
\hline Vitamin A (mcg) & 1200 & 1200 & 1200 & 1600 \\
\hline Source: Food & & &
\end{tabular}

Source: Food and Nutrition Board 




Table 3: Socio demographic characteristics of the children in Kisumu County

\begin{tabular}{|c|c|c|c|}
\hline \multicolumn{2}{|l|}{ Characteristics } & \multirow{2}{*}{$\begin{array}{c}\text { Frequency }(\mathbf{n}=\mathbf{1 9 2}) \\
97\end{array}$} & \multirow{2}{*}{$\begin{array}{c}\% \\
50.52\end{array}$} \\
\hline Child's sex & Girls & & \\
\hline & Boys & 95 & 49.48 \\
\hline Age & (Average(SD)) & 11.85 & 6.90 \\
\hline \multirow[t]{4}{*}{ Child's Age group } & $\leq 6$ & 39 & 20.31 \\
\hline & 6 to $\leq 12$ & 57 & 29.69 \\
\hline & 12 to $\leq 18$ & 57 & 29.69 \\
\hline & 18 to $\leq 24$ & 39 & 20.31 \\
\hline \multirow[t]{2}{*}{ Mother's marital status } & Single & 42 & 21.77 \\
\hline & Married & 150 & 68.23 \\
\hline \multirow[t]{2}{*}{ Mother income (Ksh) } & $\leq 3000.00$ & 152 & 79.21 \\
\hline & $\geq 3001.00$ & 40 & 20.79 \\
\hline \multirow[t]{2}{*}{ Father's income (Ksh) } & $\leq 3000.00$ & 119 & 61.98 \\
\hline & $\geq 3001.00$ & 73 & 38.02 \\
\hline \multirow[t]{3}{*}{ Mother's Education } & $\leq$ Primary & 69 & 35.94 \\
\hline & Secondary & 76 & 39.58 \\
\hline & Tertiary & 47 & 24.48 \\
\hline \multirow[t]{2}{*}{ Type of housing } & Not permanent & 105 & 54.69 \\
\hline & Permanent & 87 & 45.31 \\
\hline \multirow[t]{3}{*}{ Size of housing } & Single & 66 & 34.38 \\
\hline & Double & 80 & 41.67 \\
\hline & $\geq 3$ rooms & 46 & 23.96 \\
\hline \multirow[t]{3}{*}{ Rent amount (Ksh) } & None & 63 & 32.81 \\
\hline & $\leq 3000.00$ & 87 & 45.31 \\
\hline & $\geq 3001.00$ & 42 & 21.88 \\
\hline \multirow[t]{2}{*}{ Mother own phone } & Yes & 183 & 95.31 \\
\hline & No & 9 & 4.69 \\
\hline
\end{tabular}

$* 100.00 \mathrm{Ksh}$ is equivalent to $1 \mathrm{USD}$ 


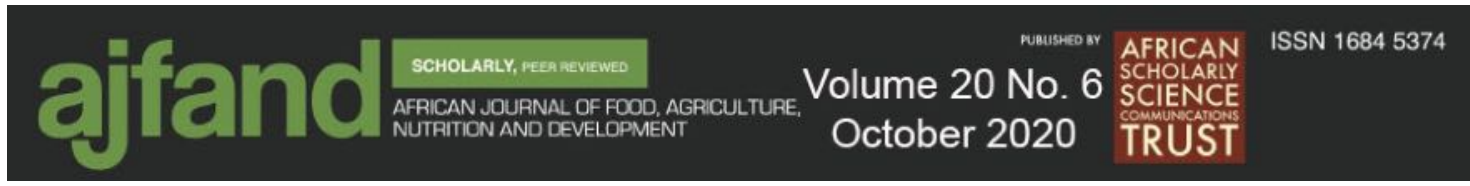

Table 4: Adequacy of Nutrient intake among chidlren in Kisumu County

\begin{tabular}{|c|c|c|c|c|c|}
\hline \multirow{2}{*}{$\begin{array}{c}\text { Age group } \\
\text { (months) }\end{array}$} & \multicolumn{5}{|c|}{ Nutrient intake adequacy in $\%(n=192)$} \\
\hline & Carbohydrate & Protein & Fat & Iron & Vitamin A \\
\hline$<6$ & 94.87 & 51.28 & 84.62 & 48.72 & 92.31 \\
\hline $6-12$ & 87.72 & 33.33 & 78.95 & 31.58 & 78.95 \\
\hline $13-18$ & 94.74 & 33.33 & 64.10 & 31.58 & 79.49 \\
\hline $19-24$ & 82.08 & 20.51 & 71.93 & 12.82 & 85.95 \\
\hline Total & 90.12 & 34.37 & 75.00 & 31.72 & 83.85 \\
\hline Statistics & $\begin{array}{l}\mathrm{Chi}^{2}=5.566 \\
\mathrm{p}=1.135\end{array}$ & $\begin{array}{l}\mathrm{Chi}^{2}=8.318 \\
\mathrm{p}=0.040\end{array}$ & $\begin{array}{l}\mathrm{Chi}^{2}=0.16, \\
\mathrm{p}=0.161\end{array}$ & $\begin{array}{l}\text { Chi }^{2}=11.7102, \\
\text { p }=0.008\end{array}$ & $\begin{array}{l}\mathrm{Chi}^{2}=3.8091, \\
\mathrm{p}=283\end{array}$ \\
\hline
\end{tabular}

Table 5: Relationship between cognitive scores and dietary intake among children in Kisumu County

\begin{tabular}{|c|c|c|c|c|}
\hline \multirow{2}{*}{ Nutrient intake } & \multicolumn{3}{|c|}{ Cognitive scores in \% $(n=192)$} & \multirow[t]{2}{*}{ Statistics } \\
\hline & Below average & Average & Above average & \\
\hline \multicolumn{5}{|c|}{ Carbohydrate intake } \\
\hline Adequate & 25.43 & 64.74 & 9.83 & \\
\hline Inadequate & 21.05 & 47.37 & 31.58 & $\mathrm{Chi}^{2}=7.7133, \mathrm{p}=0.021$ \\
\hline \multicolumn{5}{|l|}{ Protein Intake } \\
\hline Adequate & 22.73 & 63.64 & 13.64 & \\
\hline Inadequate & 26.19 & 62.70 & 11.11 & $\mathrm{Chi}^{2}=0.444, \mathrm{p}=0.801$ \\
\hline \multicolumn{5}{|l|}{ Fat intake } \\
\hline Adequate & 25.69 & 64.58 & 9.72 & \\
\hline Inadequate & 22.92 & 58.33 & 18.75 & $\mathrm{Chi}^{2}=0.7835, \mathrm{p}=0.011$ \\
\hline \multicolumn{5}{|l|}{ Iron intake } \\
\hline Adequate & 25.00 & 61.67 & 13.33 & $\mathrm{Chi}^{2}=0.1590, \mathrm{p}=0.022$ \\
\hline Inadequate & 25.00 & 63.64 & 11.36 & \\
\hline \multicolumn{5}{|c|}{ Vitamin A intake } \\
\hline Adequate & 26.09 & 62.11 & 11.80 & \\
\hline Inadequate & 19.35 & 67.74 & 12.90 & $\mathrm{Chi}^{2}=0.6283, \mathrm{p}=0.030$ \\
\hline
\end{tabular}




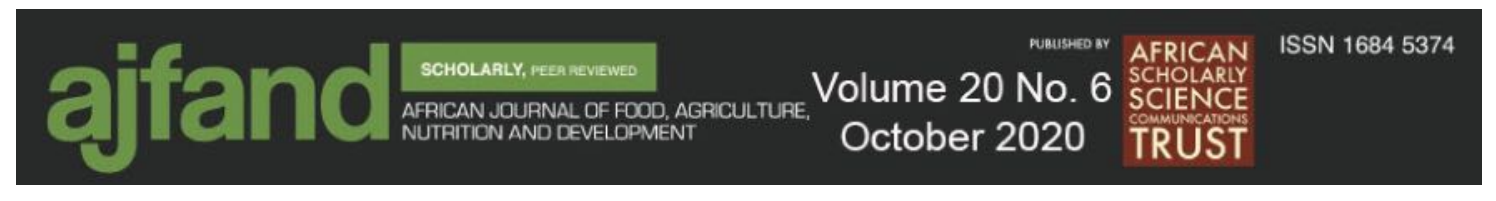

Table 6: Demographic Characteristics with cognitive scores and dietary intake among children in Kisumu County

\begin{tabular}{|c|c|c|c|c|c|c|c|c|}
\hline \multirow[t]{2}{*}{ Characteristics } & \multirow[t]{2}{*}{$(\%)$} & \multicolumn{2}{|c|}{ Cognitive scores in $\%(n=192)$} & \multicolumn{5}{|c|}{ Dietary intake adequacy in $\%(n=192)$} \\
\hline & & Below average & Above average & Carbohydrate & Protein & Fat & Iron & Vitamin A \\
\hline \multicolumn{9}{|l|}{ Child's sex } \\
\hline Girls & 50.52 & 23.71 & 12.37 & 93.81 & 35.05 & 77.32 & 31.96 & 86.60 \\
\hline Boys & 49.48 & 26.32 & 11.58 & 86.32 & 33.68 & 72.68 & 30.53 & 81.05 \\
\hline P value & & \multicolumn{2}{|c|}{0.914} & 0.082 & 0.842 & 0.453 & 0.830 & 0.296 \\
\hline \multicolumn{9}{|c|}{ Child's Age group } \\
\hline$\leq 6$ & 20.31 & 33.33 & 5.13 & 94.87 & 51.28 & 84.62 & 48.72 & 92.31 \\
\hline 6 to $\leq 12$ & 29.69 & 29.82 & 5.26 & 87.72 & 33.33 & 78.95 & 31.58 & 78.95 \\
\hline 12 to $\leq 18$ & 29.69 & 22.81 & 22.81 & 94.74 & 33.33 & 64.10 & 31.58 & 79.49 \\
\hline 18 to $\leq 24$ & 20.31 & 12.82 & 12.82 & 82.08 & 20.51 & 71.93 & 12.82 & 85.95 \\
\hline P value & & \multicolumn{2}{|c|}{0.022} & 1.135 & 0.040 & 0.161 & 0.008 & 0.283 \\
\hline \multicolumn{9}{|c|}{ Mother's marital status } \\
\hline Single & 21.77 & 31.15 & 14.15 & 96.72 & 29.51 & 86.89 & 26.23 & 81.97 \\
\hline Married & 68.23 & 22.14 & 9.30 & 87.02 & 36.64 & 69.47 & 33.59 & 84.73 \\
\hline$P$ value & & \multicolumn{2}{|c|}{0.383} & 0.036 & 0.333 & 0.009 & 0.306 & 6.28 \\
\hline \multicolumn{9}{|c|}{ Mother income (Ksh) } \\
\hline$\leq 3000.00$ & 79.21 & 21.70 & 14.15 & 85.35 & 47.17 & 66.04 & 43.40 & 82.08 \\
\hline$\geq 3001.00$ & 20.79 & 29.07 & 9.30 & 95.35 & 18.6 & 86.05 & 16.28 & 86.05 \\
\hline$P$ value & & \multicolumn{2}{|c|}{0.366} & 0.028 & $<0.001$ & 0.001 & $<0.001$ & 0.457 \\
\hline \multicolumn{9}{|c|}{ Father's income (Ksh) } \\
\hline$\leq 3000.00$ & 61.98 & 26.05 & 15.13 & 90.76 & 32.77 & 72.27 & 27.73 & 83.19 \\
\hline$\geq 3001.00$ & 38.02 & 23.29 & 6.85 & 89.04 & 36.99 & 79.45 & 36.99 & 84.93 \\
\hline P value & & \multicolumn{2}{|c|}{0.165} & 0.699 & 0.551 & 0.264 & 0.179 & 0.751 \\
\hline
\end{tabular}




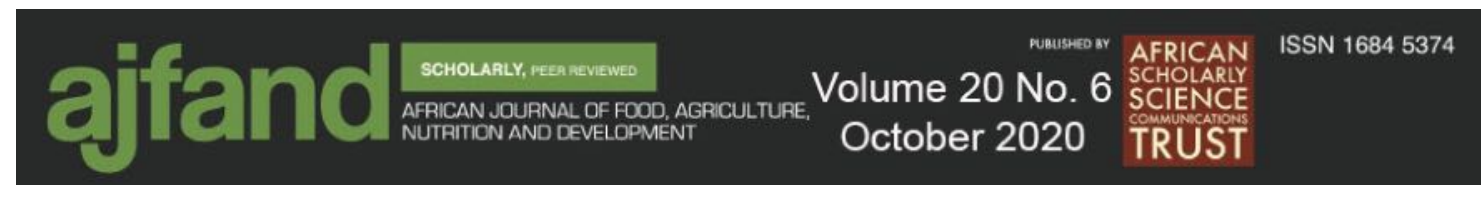

\begin{tabular}{|c|c|c|c|c|c|c|c|c|}
\hline \multicolumn{9}{|c|}{ Mother's Education } \\
\hline$\leq$ Primary & 35.94 & 23.19 & 15.94 & 86.96 & 55.07 & 65.22 & 49.28 & 85.51 \\
\hline Secondary & 39.58 & 27.63 & 9.21 & 90.79 & 23.68 & 80.26 & 22.37 & 82.89 \\
\hline Tertiary & 24.48 & 23.40 & 10.64 & 93.62 & 21.28 & 80.85 & 19.15 & 82.98 \\
\hline P value & & \multicolumn{2}{|r|}{0.749} & 0.483 & $<0.001$ & 0.064 & $<0.001$ & 0.897 \\
\hline \multicolumn{9}{|c|}{ Type of housing } \\
\hline Not permanent & 54.69 & 28.57 & 9.52 & 97.14 & 26.67 & 87.62 & 25.71 & 84.76 \\
\hline Permanent & 45.31 & 20.69 & 14.94 & 81.61 & 43.68 & 59.77 & 37.93 & 82.76 \\
\hline$P$ value & & \multicolumn{2}{|r|}{0.302} & $<0.001$ & 0.013 & 0.067 & 0.069 & 0.707 \\
\hline \multicolumn{9}{|l|}{ Size of housing } \\
\hline Single & 34.38 & 22.73 & 13.64 & 90.91 & 43.94 & 72.73 & 40.91 & 80.30 \\
\hline Double & 41.67 & 27.50 & 13.75 & 90.00 & 36.25 & 75.00 & 32.50 & 87.50 \\
\hline$\geq 3$ rooms & 23.96 & 23.91 & 6.52 & 89.13 & 17.39 & 78.26 & 15.22 & 82.61 \\
\hline $\bar{P}$ value & \multicolumn{2}{|r|}{0.661} & & 0.952 & 0.013 & 0.801 & 0.015 & 0.84 \\
\hline \multicolumn{9}{|c|}{ Rent amount (Ksh) } \\
\hline None & 32.81 & 22.22 & 12.70 & 95.24 & 26.98 & 88.89 & 74.60 & 73.02 \\
\hline$\leq 3000.00$ & 45.31 & 25.29 & 12.64 & 87.36 & 43.68 & 65.52 & 25.40 & 88.51 \\
\hline$\geq 3001.00$ & 21.88 & 28.57 & 9.52 & 88.10 & 26.19 & 75.00 & 21.43 & 90.48 \\
\hline$P$ value & & \multicolumn{2}{|r|}{0.107} & 0.248 & 0.047 & 0.005 & 0.046 & 0.016 \\
\hline \multicolumn{9}{|c|}{ Mother own phone } \\
\hline Yes & 95.31 & 25.14 & 12.57 & 86.62 & 33.88 & 76.50 & 31.15 & 84.15 \\
\hline No & 4.69 & 22.22 & 0.00 & 100.00 & 44.44 & 44.44 & 33.33 & 77.78 \\
\hline P value & & \multicolumn{2}{|r|}{0.476} & 0.309 & 0.515 & 0.030 & 0.89 & 0.612 \\
\hline
\end{tabular}




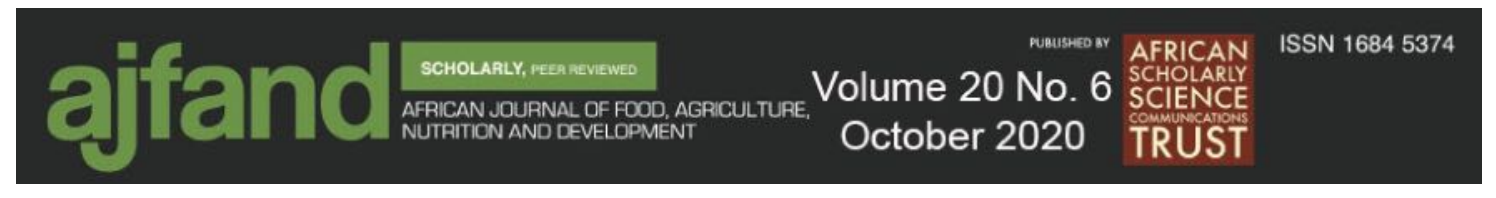

Table 7: Relationship between demographic characteristics, cognitive scores and dietary intake among children in Kisumu County

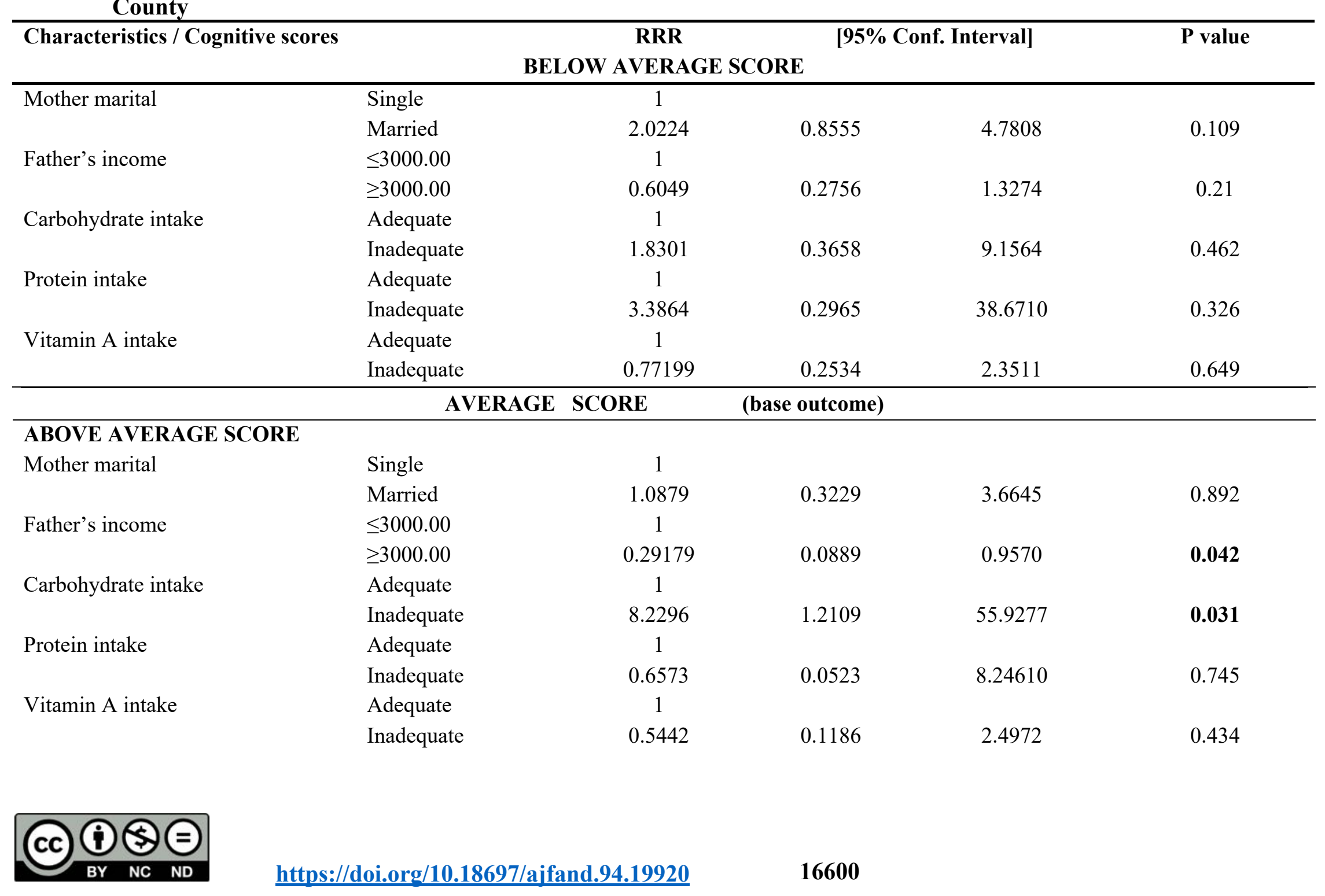




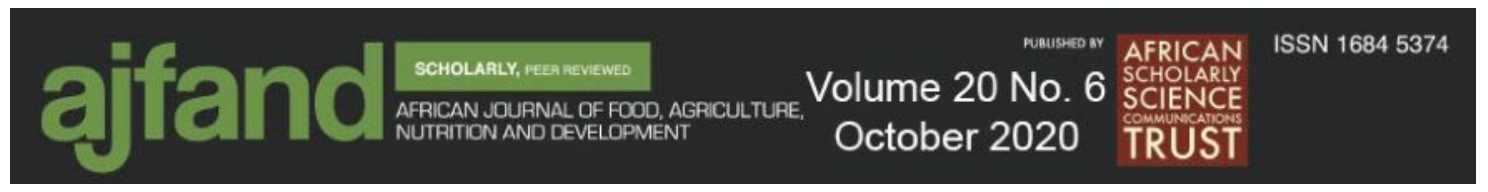

\section{REFERENCES}

1. Bayley N Bayley-III: Bayley Scales of infant and toddler development. Giunti OS;2009.

2. Zauche LH, Thul TA, Mahoney AED and JL Stapel-Wax Influence of language nutrition on children's language and cognitive development: An integrated review. Early Childhood Research Quarterly. 2016; 36:318-33.

3. Edmunds LS, Woelfel ML, Dennison BA, Stratton H, Pruzek RM and R Abusabha Overweight trends among children enrolled in the New York State special supplemental nutrition program for women, infants, and children. Journal of the American Dietetic Association. 2006;106(1):113-7.

4. Grantham-McGregor S, Cheung YB, Cueto S, Glewwe P, Richter L and B Strupp Developmental potential in the first 5 years for children in developing countries. The Lancet. 2004;369(9555):60-70.

5. Greenwood $\mathbf{C}$ and RA Craig Dietary influences on brain function: implications during periods ofneuronal maturation. Current topics in nutrition and disease. 1987.

6. Isaacs $\mathbf{E}$ and $\mathbf{J}$ Oates Nutrition and cognition: assessing cognitive abilities in children and young people. European journal of nutrition. 2008;47(3):4-24.

7. Freeman HE, Klein RE, Townsend JW and A Lechtig Nutrition and cognitive development among rural Guatemalan children. American Journal of Public Health. 1980;70(12):1277-85.

8. Children St. Nutrition in the first 1,000 Days State of the World's Mothers, Brookstone,: Johnson \& Johnson, Mattel, Inc; 2012.

9. Anderson JW, Johnstone BM and DT Remley Breast-feeding and cognitive development: a meta-analysis. The American Journal of Clinical Nutrition. 1999;70(4):525-35.

10. World Health Organization. The optimal duration of exclusive breastfeeding: a systematic review. Geneva: World Health Organization, 2001.

11. Kenya National Bureau of Statistics (KNBS) and ICF Macro. Kenya demographic and health survey, 2014. 2014, KNBS and ICF Macro, Calverton, Maryland 2014.

12. De Jager CA and $\mathbf{S}$ Ahmed Research on the Effects of Vitamins and Minerals on Cognitive Function in Older Adults, in Nutrition for Brain Health and Cognitive Performance. CRC Press; 2015. p.204-35. 


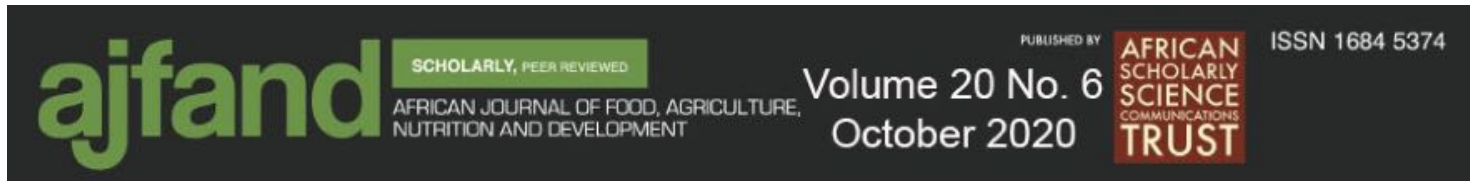

13. Srivastava A, Mahmood SE, Srivastava PM, Shrotriya VP and B Kumar Nutritional status of school-age children - A scenario of urban slums in India. Arch Public Health. 2012;70(1):8.

14. Black MM Zinc deficiency and child development. The American Journal of Clinical Nutrition. 1998:68(2):464S-69S.

15. Neumann CG, Bwibo NO, Murphy SP, Sigman M, Whaley S, Allen LH, Guthrie D, Weiss RE and MW Demment Animal Source Foods Improve Dietary Quality, Micronutrient Status, Growth and Cognitive Function in Kenyan School Children: Background, Study Design and Baseline Findings. The Journal of Nutrition. 2003;133(11):3941S-49S.

16. Glewwe $\mathbf{P}$ and EM King The Impact of Early Childhood Nutritional Status on Cognitive Development: Does the Timing of Malnutrition Matter? The World Bank Economic Review. 2001;15(1)81-113.

17. Crookston BT, Schott W, Cueto S, Dearden KA, Engle P, Georgiadis A, Lundeen EA, Penny ME, Stein AD and JR Behrman Postinfancy growth, schooling, and cognitive achievement: Young Lives. The American Journal of Clinical Nutrition. 2013;98(6):1555-63.

18. Grantham-McGregor SM, Fernald LC and K Sethuraman Effects of health and nutrition on cognitive and behavioural development in children in the first three years of life. Part 1: Low birthweight, breastfeeding, and protein-energy malnutrition. Food \& Nutrition Bulletin. 1999;20(1):53-75.

19. World Health Organization. World health statistics 2010. 2010; Available from: https://apps.who.int/iris/bitstream/handle/10665/43895/9789241596664_eng.pdf. Date accessed; $3^{\text {rd }}$ March, 2020.

20. Black RE, Allen LH, Bhutta ZA, Caulfield LE, De Onis M, Ezzati M, Mathers $\mathbf{C}$ and $\mathbf{J}$ Rivera Maternal and child undernutrition: global and regional exposures and health consequences. The lancet. 2008;371(9608):243-60.

21. Martorell $\mathbf{R}$ Physical growth and development of the malnourished child: contributions from 50 years of research at INCAP. Food Nutr Bull. 2010;31(1)6882.

22. Engle PL and PD Fernández INCAP studies of malnutrition and cognitive behavior. Food \& Nutrition Bulletin. 2010;31(1):83-94.

23. Whaley SE, Sigman M, Neumann C, Bwibo N, Guthrie D, Weiss RE, Alber S and Murphy SP The impact of dietary intervention on the cognitive development of Kenyan school children. The Journal of nutrition. 2003;133(11):3965S-71S. 


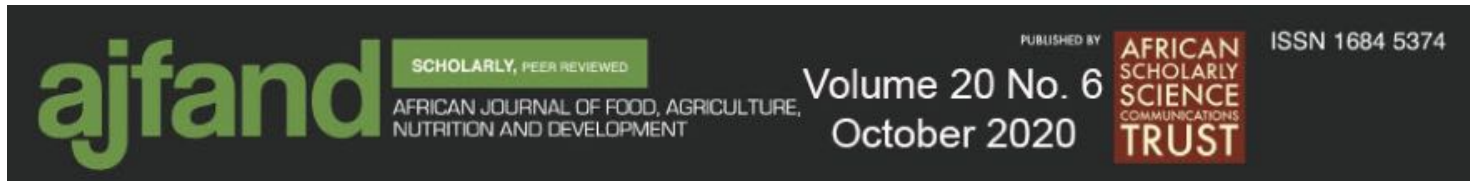

24. Anderson PJ, De Luca CR, Hutchinson E, Roberts $G$ and LW Doyle Underestimation of developmental delay by the new bayley-iii scale. Archives of Pediatrics \& Adolescent Medicine. 2010;164(4):352-56.

25. Food and Nutrition Board, and IOM. Dietary reference intakes for energy, carbohydrate, fiber, fat, fatty acids, cholesterol, protein, and amino acids (macronutrients). National Academy Press Washington (DC); 2005.

26. Ijarotimi $\mathbf{O}$ and $\mathbf{F}$ Ashipa Evaluation of nutritional composition, sensory and physical property of home processed weaning food based on low cost locally available food materials. Nutrition \& Food Science. 2006.

27. Fomon SJ Nutrition of normal infants: Mosby-Year Book, Inc. 1993.

28. Goldbohm RA, Rubingh CM, Lanting CI and KF Joosten Food consumption and nutrient intake by children aged 10 to 48 months attending day care in the Netherlands. Nutrients. 2016;8(7):428.

29. Hamner HC, Perrine CG and KS Scanlon Usual intake of key minerals among children in the second year of life, NHANES 2003-2012. Nutrients. 2016;8(8)468.

30. MacRae J, O'Reilly $\mathbf{L}$ and $\mathbf{P}$ Morgan Desirable characteristics of animal products from a human health perspective. Livestock Production Science. 2005;94(1): 95-103.

31. Olson CR and CV Mello Significance of vitamin A to brain function, behavior and learning. Molecular nutrition \& food research. 2010;54(4):489-95.

32. Cabrera $\mathbf{N}$ and $\mathbf{H E}$ Peters Public policies and father involvement. Marriage \& family review. 2000;29(4):295-314.

33. Kanoski SE and TL Davidson Western diet consumption and cognitive impairment: Links to hippocampal dysfunction and obesity. Physiology \& Behavior. 2011;103(1):59-68.

34. Fungo R, Muyonga JH, Kabahenda M, Okia CA and L Snook Factors influencing consumption of nutrient rich forest foods in rural Cameroon. Appetite.2016;97:176-84.

35. Dunford E, Trevena H, Goodsell C, Ng KH, Webster J, Millis A, Goldstein S, Hugueniot $\mathbf{O}$ and $B$ Neal FoodSwitch: a mobile phone app to enable consumers to make healthier food choices and crowdsourcing of national food composition data. JMIR mHealth and uHealth. 2014;2(3):e37. 